\title{
Plasma spot welding of ferritic stainless steels $\left(^{(\cdot)}\right.$
}

\author{
A. Lešnjak* and J. Tušek*
}

\begin{abstract}
Plasma spot welding of ferritic stainless steels is studied. The study was focused on welding parameters, plasma and shielding gases and the optimum welding equipment. Plasma-spot welded overlap joints on a $0.8 \mathrm{~mm}$ thick ferritic stainless steel sheet were subjected to a visual examination and mechanical testing in terms of tension-shear strength. Several macro specimens were prepared. Plasma spot welding is suitable to use the same gas as shielding gas and as plasma gas, i.e., a $98 \% \mathrm{Ar} / 2 \% \mathrm{H}_{2}$ gas mixture. Tension-shear strength of plasma-spot welded joints was compared to that of resistance-spot welded joints. It was found that the resistance welded joints withstand a somewhat stronger load than the plasma welded joints due to a larger weld spot diameter of the former. Strength of both types of welded joints is approximately the same.
\end{abstract}

Keywords Plasma spot welding. Ferritic stainless steel. Shielding gas. Plasma gas. Overlap joint.

\section{Soldeo de aceros inoxidables ferríticos por puntos con plasma}

\begin{abstract}
Resumen El artículo describe el proceso de soldeo de aceros inoxidables ferríticos por puntos con plasma. La investigación se centró en el establecimiento de los parámetros óptimos de la soldadura, la definición del gas de plasma y de protección más adecuado, así como del equipo óptimo para la realización de la soldadura. Las uniones de láminas de aceros inoxidables ferríticos de $0,8 \mathrm{~mm}$ de espesor, soldadas a solape por puntos con plasma, se inspeccionaron visualmente y se ensayaron mecánicamente mediante el ensayo de cizalladura por tracción. Se realizaron macro pulidos. Los resultados de la investigación demostraron que la solución más adecuada para el soldeo por puntos con plasma es elegir el mismo gas de plasma que de protección. Es decir, una mezcla de $98 \%$ de argón y $2 \%$ de hidrógeno. La resistencia a la cizalladura por tracción de las uniones soldadas por puntos con plasma fue comparada con la resistencia de las uniones soldadas por resistencia por puntos. Se llegó a la conclusión de que las uniones soldadas por resistencia soportan una carga algo mayor que la uniones soldadas por puntos con plasma debido a que el diámetro del punto de soldadura es en el primer caso mayor. La resistencia en los dos tipos de soldaduras es aproximadamente igual.
\end{abstract}

Palabras clave Soldeo plasma por puntos. Lámina de acero inoxidable ferrítico. Gas de protección. Gas de plasma. Unión soldada a solape.

\section{INTRODUCTION}

Plasma spot welding has been little investigated and almost not applied to spot welding of lap or parallel joints in the industrial practice. In the literature no paper treating plasma spot welding as such from an experimental or theoretical viewpoint could be found. No paper or other information on plasma spot welding of ferritic stainless steels could be found either.
Initial studies have shown that in mass production plasma spot welding will never be able to completely substitute for resistance spot welding. Plasma spot welding, however, can in certain cases substitute for or complement other welding processes. The greatest advantage of plasma spot welding consists in a chance to weld from one side only and in low cost of maintenance since there is no electrode wear.

(•) Trabajo recibido el día 15 de febrero de 2002 y aceptado en su forma final el día 3 de Junio de 2002.

(*) Welding Institute, Ptujska 19, 1000 Ljubljana, Slovenia 
The goal of the investigations conducted was to find whether plasma spot welding is suitable for welding of ferritic stainless steels, to make plasma spot welding easy to apply and establish its possible advantages over resistance spot welding. This required determination of optimum welding parameters, first of all welding current and weld time. This could be done only by carefully analysis of welded joints obtained under different conditions. The analysis was focused on the macrostructure and microstructure of the weld obtained and mechanical properties of the joint.

\section{FERRITIC STAINLESS STEELS}

Ferritic stainless steels are the simplest of all stainless steels. They are based on a system $\mathrm{Fe}-\mathrm{Cr}$ $\mathrm{C}$ and contain at least $11-12 \% \mathrm{Cr}$. It is the $\mathrm{Cr}$ content that affects the steel microstructure since $\mathrm{Cr}$ is an element that widens the $\alpha$ field whereas carbon has a strong influence on the microstructure and widens the $\delta$ field. With a comparatively low content of $\mathrm{Cr}$, a partial $\delta-\gamma$ transformation and, consequently, the ferritic/austenitic structure will always occur. With a sufficient $\mathrm{Cr}$ content the microstructure is ferritic in the entire temperature range ${ }^{[1]}$.

The ferritic stainless steels are classified into three groups ${ }^{[2}$ and 3$]$ :

- steels with $11-13 \% \mathrm{Cr}$; they are used in not too aggressive media and are an alternative to $\mathrm{C}$ Mn steels;

- steels with 16-19 \% Cr; they can be used in mildly aggressive media if $\mathrm{Mo}$ is added to improve corrosion resistance;

- steels with $25 \%$ and more Cr; they have very good point-corrosion and cavitation-corrosion resistance; they have a good resistance to saltwater corrosion.

\subsection{Brittleness}

The ferritic stainless steels have a body-centered cubic lattice, which represents a great deficiency. Such a structure is characterised by a transition temperature which is particularly high with stainless steels. In addition, the following phenomena are characteristic of these steels ${ }^{[4-18]}$ :

- brittleness at $475^{\circ} \mathrm{C}$,

- formation of sigma phase,
- formation of martensite,

- brittleness due to heating up to elevated temperatures.

\section{PLASMA WELDING}

Plasma arc welding is an arc welding process that produces the bonding of welded metals by heating them with a constricted arc between an electrode and the workpiece (transferred arc) or between the electrode and the constricting nozzle (nontransferred arc). It is basically an extension of the tungsten inert gas welding (TIG welding). It differs from TIG welding, however, in that the plasma burner has a special constricting nozzle through which the gas is forced and constricted. Because of a high temperature the gas becomes ionised in the arc to form the plasma, and issues from the orifice in the burner nozzle as a plasma jet with a core temperature of around $16700^{\circ} \mathrm{C}^{[19-22]}$. The plasma jet being very narrow it permits a better control of the direction of melting and, consequently, a smaller heat-affected zone $(\mathrm{HAZ})^{[23]}$.

The main advantages of plasma arc welding over TIG welding are as follows:

- higher welding speeds,

- lower energy input,

- weaker deformation,

- easier control of penetration depth,

- greater directional stability of the arc,

- a narrower weld pool,

- a higher energy efficiency.

The limitations include:

- the need for accurate joint alignment of sheets,

- considerable cost of constricting nozzles to be changed.

\subsection{Plasma and shielding gases}

The selection of plasma and shielding gases depends primarily on the material to be welded. In general the same gas will be used as the plasma gas as well as the shielding gas. The only condition is that the plasma gas is inert so that neither electrode damage nor burn-off may occur. On the contrary, the shielding gas may be active, most often to reduce the surface tension of the weld pool.

The most frequently used shielding gas is argon. It has a low ionisation potential, which makes arc 
ignition, i.e. pilot-arc burning, easier. In addition it is very suitable for reactive materials such as titanium and zirconium.

In welding of stainless steels, nickel and its alloys, an argon/hydrogen mixture will be used. The mixture should contain up to $15 \%$ hydrogen at maximum, but commonly there is around $5 \%$ of hydrogen. The quantity of hydrogen is inversely proportional to the workpiece thickness ${ }^{[24-31]}$.

\section{EXPERIMENTAL METHOD}

The aim of the investigation was to find out whether plasma spot welding is suitable for overlap welding of the ferritic stainless steel sheets with a thickness of $0.8 \mathrm{~mm}$. Thus optimum welding parameters, optimum plasma and shielding gases, and the advantages of plasma spot welding over resistance spot welding were established.

For the experiments, a thyristor current source with a stepless setting of welding current from 0 to $85 \mathrm{~A}$ and, a current up-slope time at the beginning of welding, and a current down-slope time at the end of welding from 0 to $1.5 \mathrm{~s}$. The device also permits an extended blowing-in of the shielding gas after welding in order to protect the electrode and the weld spot. The nozzles with a diameter of $1.6 \mathrm{~mm}$ were used for currents up to $70 \mathrm{~A}$ and those with a diameter of $2.3 \mathrm{~mm}$ for currents up to $85 \mathrm{~A}$. With very low currents, i.e., below $40 \mathrm{~A}$, nozzles with a diameter of 1.2 should be used. With the nozzles used, the ratios between the length and the orifice diameter were 0.53 and 0.77 respectively.

The current source had a weld timer for spot welding built-in. The timer permits a stepless digital setting of weld time. It trigs only after the transferred arc between the electrode and the workpiece has started burning.

Setting of current up-slope and down-slope times was stepless and analogous between 0 and 1.5 s. It turned out that the time of the current downslope from the maximum value to $0 \mathrm{~A}$ was extremely important. An appropriate current down-slope, namely, permits filling of the crater. If current down-slope from the maximum value to 0 A is momentary, the crater will not be filled.

The test pieces were welded under different conditions in order to find the most suitable welding technique and its suitability for welding of the ferritic stainless steels ${ }^{[15]}$.

The weld time was determined experimentally. It was studied, on the one hand, after how long a weld has not been formed yet, and on the other hand, in which moment sagging, i.e., partial outflow, of the weld spot at the lower sheet occurs.

The test pieces were welded by overlapping two sheets. No additional force was used to improve the contact between the sheets. The reason was that in practice the application of pressure often produces good contact between two sheets, but sometimes it does not. Consequently, the application of no pressure is the worst case in which this process is still applicable. When using plasma spot welding with a complex workpiece, attention should be paid that a minimum contact is assured and that the spots are not too close to each other so that buckling of the plates after several spots have been produced in a line cannot occur. In the case of buckling further welding is, namely, not possible.

Several mechanical tests were performed to establish the quality of welded spots. With the tension-shear test it was found that the dissipation of the values measured is considerable in some cases, particularly in welding with high currents and short welding times.

Basic data on the material welded are given in table I.

The test pieces used in the tension-shear test had a size of $132 \times 25 \mathrm{~mm}$. There was an overlapping of $24 \mathrm{~mm}$. Two different gases were used in welding. As the shielding and plasma gases pure argon was used in the first case, and a $\operatorname{Ar} / 2 \%$ $\mathrm{H}_{2}$ mixture in the second.

There were several reasons for selecting the mixture with $2 \%$ of $\mathrm{H}_{2}$. The addition of hydrogen, namely, increases arc energy due to gas dissociation and ionisation and due to the thermal constriction of the plasma arc by the shielding gas, in turn, due to an improved thermal conductivity of the mixture $^{[28 \text { and } 29] .}$.

The plasma gas flow rate was determined experimentally to be 0.9 to $1.0 \mathrm{l} / \mathrm{min}$. A lower flow rate produces weak penetration whereas a higher

Table I. Actual chemical composition of the steel used and its fracture strength

Tabla I. Composición química del acero utilizado y su resistencia a la rotura

\begin{tabular}{lccccccc}
\hline Steel & Mat.No. Chemical composition [\%] & $\begin{array}{c}\text { Breaking } \\
\text { strength } \\
\text { MPa }\end{array}$ \\
\hline X3CrTi17 & 1.4510 & 0.022 & 16.16 & 0.45 & 0.014 & 460 \\
\hline
\end{tabular}


flow rate produces grooving by the weld pool as well as the crater and undercut occurrences. The flow rate was measured with a precise flow metre with a measuring range from $0-21 / \mathrm{min}$ and a measuring uncertainty of $\pm 0.06 \mathrm{l} / \mathrm{min}$.

\section{DISCUSSION OF RESULTS}

An evaluation of the welded joints included a visual examination of the weld spot and the welded joint as such, mechanical testing in terms of joint strength, and macro specimens of the weld spots. The welded joints made with pure argon as the shielding and plasma gas were subjected neither to mechanical testing nor macro examinations since the visual examination had showed that the joints were little suitable for the purpose. To obtain relevant results, thus the $0.8 \mathrm{~mm}$ thick ferritic stainless sheets were welded with the $98 \% \mathrm{Ar} / 2$ $\% \mathrm{H}_{2}$ gas mixture as the shielding and plasma gas, with currents of $40 \mathrm{~A}, 60 \mathrm{~A}$ and $80 \mathrm{~A}$, weld times of 0 to $5 \mathrm{~s}$, an current up-slope time of $0.1 \mathrm{~s}$, and a down-slope time of $1.5 \mathrm{~s}$.

\subsection{Visual assessment of the procedure and visual examination of the welded joints}

The visual assessment of the plasma spot welding process and the visual examinations of the welded joints supplied the following findings:

- The weld spot is much wider with pure argon than with the mixture because the arc is less constricted. Argon has a lower thermal conductivity than hydrogen, i.e. the $\mathrm{Ar} / \mathrm{H}_{2}$ mixture. Consequently, arc constriction with this shielding gas is inefficient.

- With a little higher energy input, a semicircular undercut and a comparatively distinctive and pointed centre crater will, as a rule, occur at the weld surface. This could be a result of too weak an arc constriction by the shielding gas. This, in turn, results in a turbulent plasma arc, i.e., plasma jet, which may produce unsymmetrical melting.

An important role in the formation of the weld pool at the surface of the weld spot is played by the weld-pool viscosity. The addition of hydrogen to the shielding gas, and even more so to the plasma gas, makes the weld pool more liquid due to a local, i.e., higher, heat input. In this way a smoother weld spot without craters and undercuts will form.
- The shape itself is strongly affected by surface tension $\gamma$ and the related Marangoni effect ${ }^{[23]}$.

- The nozzles are frequently subjected to deterioration because of spatter from the weld pool. Care should be taken that the distance between the nozzle and the workpiece is not below $5 \mathrm{~mm}$. An interesting phenomenon is a sort of arc repulsion from the workpiece to the nozzle which will damage, i.e., partly melt, the nozzle so that it may become unfit for use.

In welding at lower currents and particularly of thicker plates, there seems to be a problem with insufficient melting of the lower plate. In most cases only the upper plate will melt. If the weld time is extended, however, melting is centric no more. On the contrary, it is distinctly proceeding only in one random direction.

It is believed that the problem consists in too slow melting. Heat removal across the cross section can be, namely, strong enough to make the weld pool flow in a certain direction. There are several reasons why the weld pool should flow in a certain direction. The most conspicuous one is that the weld pool prefers to flow in the direction where there is a lack of complete contact with the lower sheet. The problem of the comparatively large plasma arc burning in pure argon should not be forgotten either.

- The arc is very stable and easy to initiate. This is particularly true of the initiation of the pilot arc. The pilot arc, namely, quite readily ignites although the electrode diameter is as large as $4.8 \mathrm{~mm}$. A massive electrode has a negative effect on the plasma-arc initiation since it does not heat readily, which is a prerequisite for a better electron emissivity. In welding with the argon/hydrogen mixture, it is difficult enough to initiate the pilot arc. A prerequisite for an efficient arc initiation are the use of a newly pointed electrode and a nozzle as clean as possible.

- A comparison was also made of welding with two different argon qualities, i.e., with argon 4.6 (99.96\% Ar) and argon 5 (99.999\% Ar). The only difference, but very obvious, was that the arc burns much better in argon 5.0. In this case the transferred arc can be initiated even if the distance between the nozzle and the workpiece ranges between 20 and $25 \mathrm{~mm}$. When welding with argon 5.0, the plasma arc will initiate when the distance between the nozzle and the workpiece is around $10 \mathrm{~mm}$. 


\subsection{Mechanical properties of welded joints on $0.8 \mathrm{~mm}$ thick sheet $\mathrm{X} 3 \mathrm{CrTi17}$}

In order to analyse the mechanical properties of the overlapping plasma spot welded joints on the ferritic stainless steels, the tension-shear test was used. With each welding-parameter setting, three test pieces of overlap welded joints were produced at minimum. The welded joints found unfit already in the visual examination were not subjected to mechanical testing. Figure 1 shows the breaking force as a function of weld time and welding current. In the experimental part of the investigation the optimum values of the welding parameters with which the welded joint carries the greatest load were to be found. A plate of $0.8 \mathrm{~mm}$ in thickness was used. As the shielding and plasma gases the $98 \% \mathrm{Ar} / 2 \% \mathrm{H}_{2}$ mixture was used. The welded joints obtained in welding in argon will not be discussed since their mechanical properties were too unfavourable. The welding currents of 40,60 and $80 \mathrm{~A}$ were used.

The diagram in figure 1 shows that the highest joint strength was obtained in welding with the current of $60 \mathrm{~A}$ and welding time of $1 \mathrm{~s}$. With longer welding times, the weld spot was overheated and, consequently, coarse grains with poor mechanical properties were obtained in its vicinity. The same happened in welding with the current of $80 \mathrm{~A}$. In welding with the current of $40 \mathrm{~A}$, however, the optimum welding time was not achieved. The curves in figure 1 show average values obtained in several tests performed.

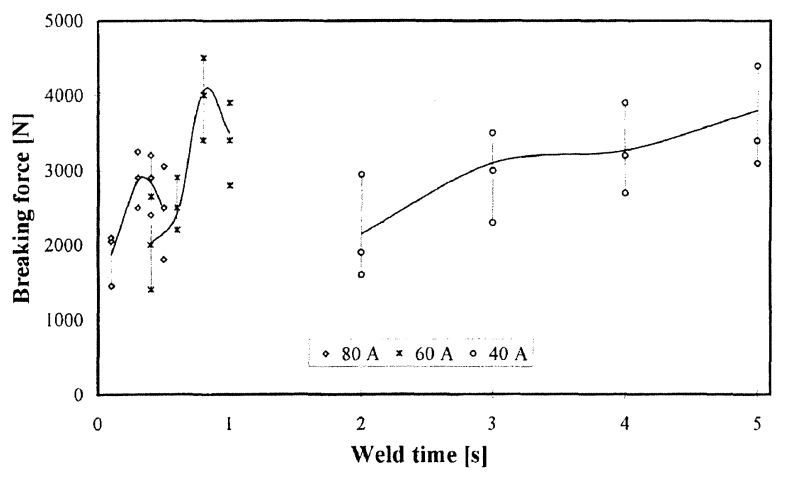

Figure 1. Breaking force as a function of welding current and weld time; $0.8 \mathrm{~mm}$ thick sheet of $\mathrm{X} 3 \mathrm{CrTi} 17$; current upslope time: $0.1 \mathrm{~s}$; shielding and plasma gases: $\mathrm{Ar} / 2 \% \mathrm{H}_{2}$.

Figura 1. Carga de rotura en función de la corriente y del tiempo de soldeo. Material: X3CrTi17, espesor: 0,8 m; tiempo de crecimiento de la corriente: $0,1 \mathrm{~s}$; gas de protección y gas de plasma: $\mathrm{Ar} / 2 \% \mathrm{H}_{2}$.
The type of gas used having a strong influence on joint strength, its influence on the weld-spot size was analysed too. The diagram in figure 2 shows the results obtained. The welding energy was calculated by multiplying the current, the plasmaarc voltage, and the welding time.

A superficial assessment itself indicates that the type of gas used has a strong influence. Thus with the same weld-spot size up to $100 \%$ more energy was consumed with pure argon than with the argon/hydrogen mixture.

The influence of the energy input on the strength of the lap welded joint was also established. The diagram in figure 3 shows the influence of energy input on the breaking force under tension-shear load. The findings are similar as in the analysis of the influence of the welding parameters on the breaking force. The optimum

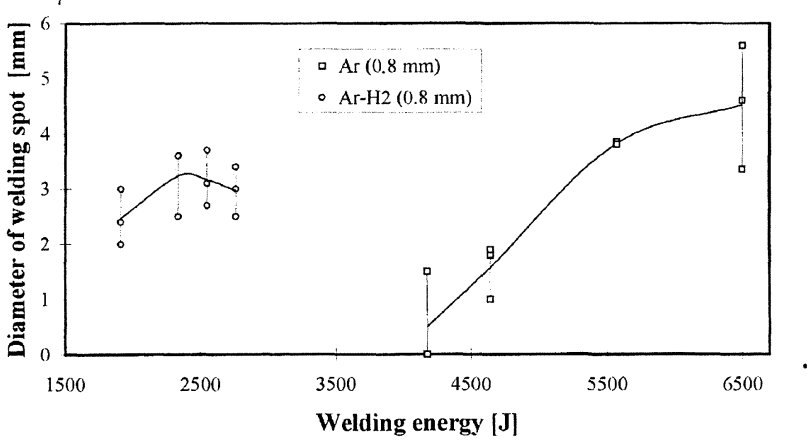

Figure 2. Diameter of weld spot as a function of welding energy; $0.8 \mathrm{~mm}$ thick sheet of $\mathrm{X} 3 \mathrm{CrTi17}$; current up-slope time: $0.1 \mathrm{~s}$.

Figura 2. Tamaño del diámetro del punto de soldadura en función de la energía de soldadura. Material: X3CrTi17, espesor: 0,8 mm; tiempo de crecimiento de la corriente: $0,1 \mathrm{~s}$.

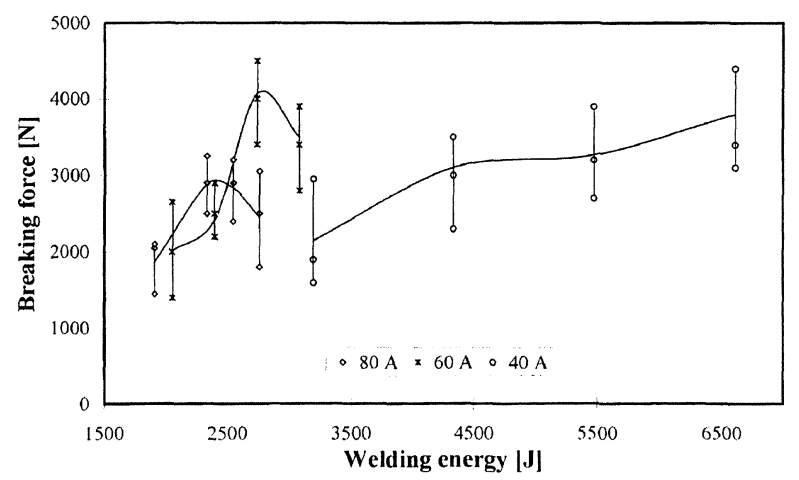

Figure 3. Breaking force as a function of welding energy; shielding and plasma gases: $\mathrm{Ar} / 2 \% \mathrm{H}_{2}$.

Figura 3. Carga de rotura en función de la energía de soldadura; gas de protección y gas de plasma: $\mathrm{Ar} / 2 \% \mathrm{H}_{2}$. 
energy input is obtained in welding with the current of $60 \mathrm{~A}$ and the energy input of $2600 \mathrm{~J}$. In welding with the current of $40 \mathrm{~A}$, however, the energy input should be much higher, i.e., around $6000 \mathrm{~J}$, if a higher joint strength is to be obtained.

\subsection{Analyses of macrostructure and microstructure of the weld spot}

In addition to the test pieces intended for mechanical testing, also test pieces for macro and micro examinations were made. The main aim was to determine the relations among the mechanical properties, the weld-spot structure, and the welding parameters, i.e., to confirm some presuppositions and conclusions already mentioned.

It has already been mentioned that the strongest influence on the weld-spot size and, consequently, its strength, is exerted by the welding current. In the examination of macro specimens, the following basic characteristics due to the increase in welding current were established:

- the structure is growing coarser,

- the degree of penetration is increasing,

- damages to the surface and the cross section respectively are increasingly conspicuous,

- the weld-spot size is increasing.

As far as the macro structures are concerned, it is interesting to make a comparison of different structures as a function of energy input, i.e., welding current and welding time. It can be observed that grain structures can change considerably although the change in energy input is comparatively small.

Figure 4a) shows that penetration was barely accomplished. It turned out, when welding several times, that such a case is less frequent than the case in which the sheets do not coalesce. The structure of the lower sheet has changed little if compared to the one shown at the edge of the photo in the unaffected zone. In the upper sheet, however, the structure has changed considerably. The grains have become so large that they reach through the entire thickness of the weld spot

Figure $4 \mathrm{~b}$ ) shows a very good penetration. As to the structure of the welded joint related to the parent metal, it is not bad at all. An undercut can be observed.

Figures $4 \mathrm{c}$ ) and $4 \mathrm{~d}$ ) shows that the weld-spot diameter increases whereas figure $4 \mathrm{~d}$ ) additionally

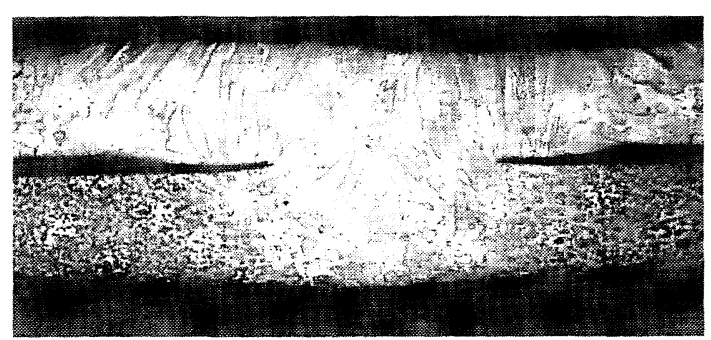

a)
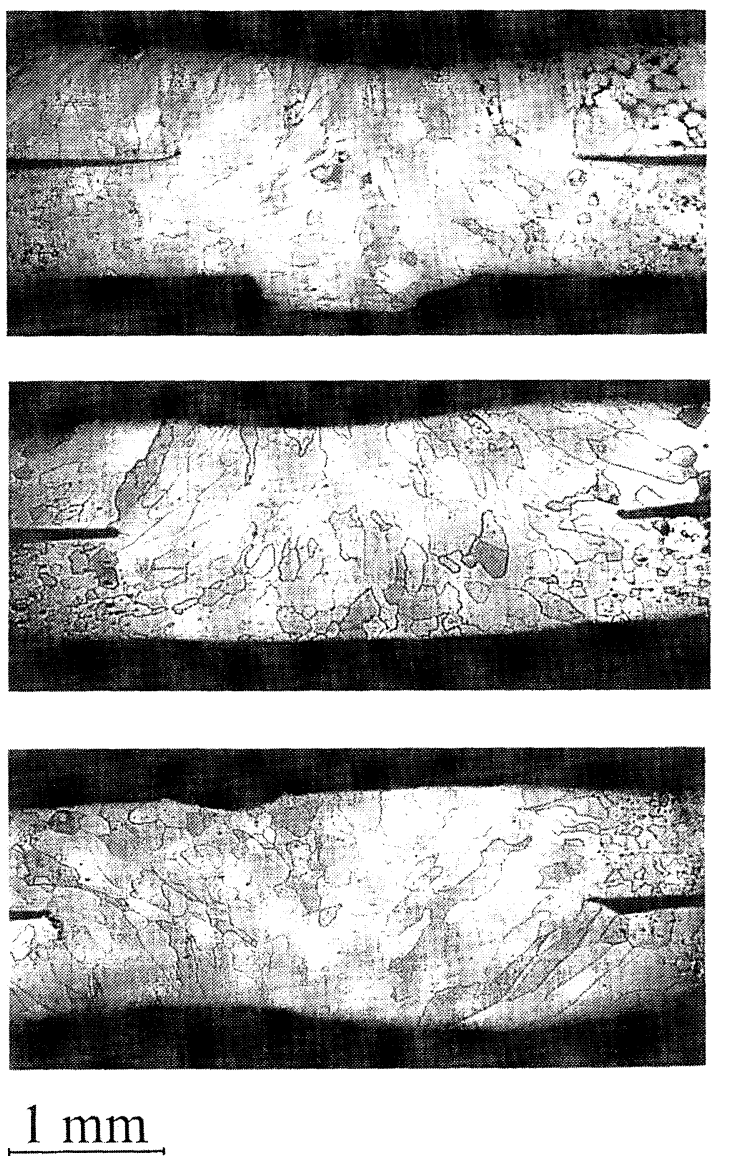

d)

Figure 4. Comparison of macrostructures of $0.8 \mathrm{~mm}$ thick steel $\mathrm{X} 3 \mathrm{CrTi17}$ obtained in welding with different energy inputs; welding current: $60 \mathrm{~A}$, current up-slope time: $0.1 \mathrm{~s}$, current down-slope time: $1.5 \mathrm{~s}, \mathrm{Ar} / \mathrm{H}_{2}$ plasma gas flow rate: $1 \mathrm{l} / \mathrm{min}$. a) maximum current time $t_{\mathrm{m}}=0.4 \mathrm{~s}$, welding energy $E=2052 \mathrm{~J}$; b) maximum current time $t_{\mathrm{m}}=0.6 \mathrm{~s}$, welding energy $E=2394 \mathrm{~J} ; \mathrm{c}$ ) maximum current time $t_{\mathrm{m}}=0.8 \mathrm{~s}$, welding energy $E=2736 \mathrm{~J}$; d) maximum current time $t_{\mathrm{m}}=$ $1.0 \mathrm{~s}$, welding energy $E=3078 \mathrm{~J}$.

Figura 4. Comparación de las macroestructuras del acero X3CrTil7 de espesor $0,8 \mathrm{~mm}$ al soldarlo con diferentes energías; corriente de soldadura: $60 \mathrm{~A}$, tiempo de crecimiento de la corriente: $0,1 \mathrm{~s}$, tiempo de caída de la corriente: $1,5 \mathrm{~s}$, paso del gas de plasma $\mathrm{Ar} / \mathrm{H}_{2}: 1 \mathrm{l} / \mathrm{min}$. a) tiempo de corriente máxima $t_{m}=0,4 \mathrm{~s}$, energía de soldadura $E=2052 \mathrm{~J}$; b) tiempo de corriente máxima $t_{m}=$ $0,6 \mathrm{~s}$, energía de soldadura $E=2394 \mathrm{~J}$; c) tiempo de corriente máxima $t_{m}=0,8 \mathrm{~s}$, energía de soldadura $E=2736$ $\mathrm{J}$; d) tiempo de corriente máxima $t_{m}=1,0 \mathrm{~s}$, energía de soldadura $E=3078 \mathrm{~J}$. 
shows that some of the grains are almost $1.0 \mathrm{~mm}$ long. The growth of crystal grains in the direction of heat removal is obvious too. Although the strongest breaking force was obtained with the test pieces welded with the same parameters as the test specimen in figure $4 \mathrm{~d}$ ), it can be stated that in terms of aesthetic and structure the test specimen in figure 4c) is more adequate. Weaker fracture strength are obtained primarily due to a smaller weld-spot diameter.

With lower currents it is found that the weld structure obtained with the shortest welding times barely permitting welding is strongly coarsegrained. Although the cross section of the weld spot is, at first impression, rather large, the mechanical properties of the joint are, however, unfavourable.

\subsection{Resistance spot welding}

Some test pieces were also resistance spot welded in order to be compared to the plasma spot welded test pieces. Advantages of the resistance spot welding process are low energy input and high welding speed. In comparison to arc welding processes, the process provides a comparatively fine-grained structure, permits high productivity, and makes the problem of the contact between the sheets negligible. Its main disadvantage, however, is that an approach from both sides is required and that the electrode wear is strong.

The welding parameters are given in table II.

The visual examination of the welded joint showed that the resistance welding process supplied smoother spots, i.e., almost without surface damage. Consequently, the difference between the plasma welded spot and the resistance welded spot is considerable. This refers to the side in contact with the plasma arc. On the contrary, the opposite side is of a similar quality as that obtained with the resistance welding process
Table II. Resistance welding parameters

Tabla II. Parámetros en el soldeo por resistencia

\begin{tabular}{lcc}
\hline & \multicolumn{2}{c}{ X3CrTi17, thickness $0.8 \mathrm{~mm}$} \\
\cline { 2 - 3 } Parameters & 1st set of welding & 2nd set of welding \\
\hline Electrode force $F$ & $3100 \mathrm{~N}$ & $3100 \mathrm{~N}$ \\
Force time $t$ & $0.12 \mathrm{~s}$ & $0.12 \mathrm{~s}$ \\
Hold time $t$ & $0.12 \mathrm{~s}$ & $0.12 \mathrm{~s}$ \\
Weld current $I$ & $10000 \mathrm{~A}$ & $10000 \mathrm{~A}$ \\
Weld time $t$ & $0.16 \mathrm{~s}$ & $0.18 \mathrm{~s}$ \\
\hline
\end{tabular}

provided the welding parameters are carefully selected.

Three test pieces for tension-shear testing were welded with each set of the welding parameters. Then they were broken ${ }^{[32]}$. The mechanical properties, i.e., tension-shear strength, of the welded joints are given in table III.

It can be seen that the tension-shear strength of the resistance spot welded joints is much lower than that of the parent metal which ranges between 460 and $470 \mathrm{MPa}$.

\subsection{Comparison of spot welded joints obtained with each process}

A comparison of the mechanical properties of spot welded joints indicated that resistance spot welding has some advantages over plasma spot welding; yet in certain cases plasma spot welding could successfully substitute for resistance spot welding.

A comparison of the results of tension-shear testing of resistance welded joints with those of plasma spot welded joints shows that:

- the breaking force applied in the tension-shear test is with resistance welded joints by up to $1000 \mathrm{~N}$ higher than the highest obtained with plasma welded joints. The difference is, to a

Table III. Tension-shear strength of resistance welded joints; material: X3CrTi17, thickness: $0.8 \mathrm{~mm}$ (average values) Tabla III. Resistencia a la cizalladura por tracción de las uniones soldadas por el método por resistencia, material: X3CrTi17, espesor: $0,8 \mathrm{~mm}$ (valores promedio)

\begin{tabular}{cccccccc}
\hline Runn. & $\begin{array}{c}\text { Welding } \\
\text { current } \\
\text { No. }\end{array}$ & $\begin{array}{c}\text { Welding } \\
\text { voltage } \\
\text { (V) }\end{array}$ & $\begin{array}{c}\text { Weld } \\
\text { time } \\
\text { (period) }\end{array}$ & $\begin{array}{c}\text { Breaking } \\
\text { force } \\
(\mathrm{N})\end{array}$ & $\begin{array}{c}\text { Spot } \\
\text { diameter } \\
(\mathrm{mm})\end{array}$ & $\begin{array}{c}\text { Tension-shear } \\
\text { strength } \\
\text { (MPa) }\end{array}$ & $\begin{array}{c}\text { Welding } \\
\text { energy } \\
(\mathrm{J})\end{array}$ \\
\hline 1 & 10000 & 1.35 & 8 & 4550.0 & 6.0 & 160.9 & 2160 \\
2 & 10000 & 1.35 & 9 & 4883.3 & 6.3 & 156.5 & 2430 \\
\hline
\end{tabular}


large extent, due to the different sizes of the weld spots;

- tension-shear stress, i.e., fracture strength per unit of cross-sectional area, is higher with plasma welding, i.e., up to $400 \mathrm{MPa}$, whereas with resistance welding it is below $250 \mathrm{MPa}$;

- the diameters of the plasma-welded spots are, in almost all cases, smaller than those of the resistance-welded spots. In the first case the diameters range between 2 and $4 \mathrm{~mm}$ and in the latter between 4 and $6 \mathrm{~mm}$;

- energy input is practically the same in both cases.

The above suppositions considered, it is obvious that in terms of strength, a plasma-welded spot can completely substitute a resistance-welded spot.

A comparison of the average, minimum and maximum values of breaking forces with plasmaspot and resistance-spot welded joints indicates that the majority of the values obtained in welding of the $0.8 \mathrm{~mm}$ thick sheet are below that required by ASME Code, Section IX. The values for plasma spot welding were chosen in the optimum range. The test specimens were welded using the argon/hydrogen mixture. The comparison is shown in table IV.

The reason that the breaking forces deviate from those specified in table IV is a comparatively small diameter of the weld spots in comparison to those obtained in resistance spot welding.

A comparison of the structure of the resistance welded joints with the plasma welded ones shows that the structure of the resistance welded joints is as coarse-grained as that of the plasma welded

Table IV. Comparison of breaking forces, steel sheet thickness: $0.8 \mathrm{~mm}$

Tabla IV. Comparación de las cargas de rotura, lámina de acero de espesor $0,8 \mathrm{~mm}$

\begin{tabular}{ccccc}
\hline $\begin{array}{c}\text { Current / set } \\
\text { of } \\
\text { parameters }\end{array}$ & $\begin{array}{c}\text { Breaking } \\
\text { force }\end{array}$ & $\begin{array}{c}\text { Breaking } \\
\text { force, } \\
\text { min. } \\
\text { average } \\
\text { (N) }\end{array}$ & $\begin{array}{c}\text { Welding } \\
\text { energy }\end{array}$ & $\begin{array}{c}\text { ASME } \\
\text { Min. } \\
\text { breaking } \\
\text { force } \\
\text { (N) }\end{array}$ \\
\hline 80 A & 2200 & 2883 & 2332 & \\
$80 \mathrm{~A}$ & 2300 & 2833 & 2544 & \\
$60 \mathrm{~A}$ & 2000 & 2416 & 2394 & 2477 \\
$60 \mathrm{~A}$ & 2800 & 2566 & 2736 & \\
Set 1 & 4450 & 4550 & 2160 & \\
Set 2 & 4500 & 4883 & 2430 & \\
\hline
\end{tabular}

Rev. Metal. Madrid 38 (2002) 210-219 joints. In addition, a solidification line between the two sheets is clearly visible, yet one might be too hasty to conclude that there is lack of spot penetration. The coarse grains are practically all oriented in the direction perpendicular to the sheet. On the surface a thin layer of fine-grained re-crystallised structure due to the plastic deformation of the material and elevated temperatures can be observed. This is shown in figure 5. A comparison of the temperature cycles in plasma welding with those in resistance welding shows that in the latter case the preheat time to an elevated temperature is very short. It is the same or similar as the weld time, i.e., $0.2 \mathrm{~s}$, yet it is long enough to permit the formation of coarse-grained structure. Consequently, it is expected that such a structure will be obtained in all case of fusion welding.

It is obvious that even with the up-to-date welding processes such as laser a comparatively coarse-grained structure would be obtained. It would be, however, reasonable to continue the research started since laser is a source providing very low and local energy input. To our mind the electron beam welding of these materials is not a

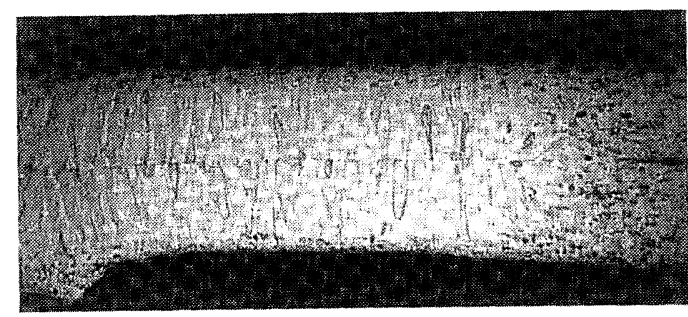

a)

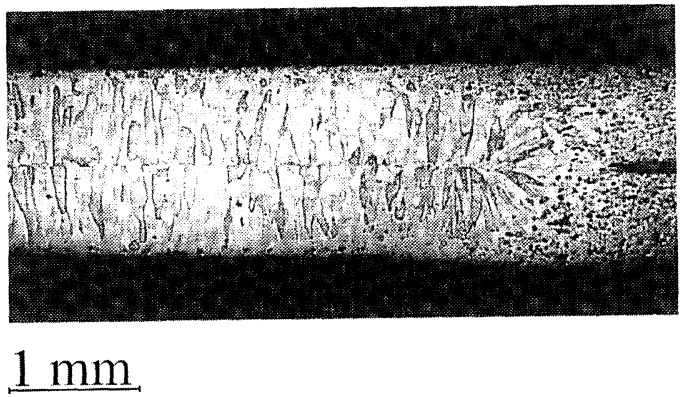

b)

Figure 5. Comparison of macrostructures of $0.8 \mathrm{~mm}$ thick steel $\mathrm{X} 3 \mathrm{CrTi17}$ obtained in welding with different sets of resistance spot welding parameters. a) Set 1 , welding energy $E=2160 \mathrm{~J}$, b) Set 2, welding energy $E=2430 \mathrm{~J}$.

Figura 5. Comparación de las macroestruras del acero $X 3 \mathrm{CrTi} 17$ de espesor $0,8 \mathrm{~mm}$ al ser soldadas por resistencia por puntos con diferentes combinaciones de parámetros; a) primera combinación, energía de soldadura $E=2160 \mathrm{~J}$; b) segunda combinación, energía de soldadura $E=2430 \mathrm{~J}$. 
very prospective application since the process is too expensive to be applied to these relatively lowcost steels.

\section{CONCLUSIONS}

The aim of the study was to establish the fitness of plasma spot welding to welding of the ferritic stainless steels.

The study of plasma spot welding of the ferritic stainless steels was promoted by the fact that very few studies accessible to the public have been conducted and the fact that the consumption of these steels is high. Thus the $0.8 \mathrm{~mm}$ thick sheets of the X3CrTi17 type were plasma spot welded. Based on the study the following conclusions can be drawn:

- The study of the influence of the plasma and shielding gases shows that the $98 \% \mathrm{Ar} / 2 \% \mathrm{H}_{2}$ mixture is the most suitable to be used both as the shielding gas and the plasma gas. A good penetration of the sheets and a smooth surface free of craters are obtained.

- If pure argon is used as the plasma gas and the shielding gas, undercuts, unsymmetrical spots, and craters as well as poor penetration in the lower sheet are obtained.

- The efficiency of the energy supplied is much greater with the argon/hydrogen mixture than with pure argon.

- The optimum limits of setting the welding parameters are relatively narrow.

- The optimum welding current is around $60 \mathrm{~A}$ for the $0.8 \mathrm{~mm}$ thick sheet.

- The welding-current up-slope is not important whereas the current down-slope strongly affects the crater filling.

- In plasma spot welding of the ferritic stainless steels it is indispensable to provide an extended weld-face protection.

- The optimum mechanical properties of the plasma spot welded joint are ensured only in a narrow range of the selected welding parameters.

- The growth of crystal grains cannot be avoided.

- With welding no hardening phenomena such as formation of martensite or sigma phase and no brittleness at $475{ }^{\circ} \mathrm{C}$ occur. The increased growth of the crystal grains does not produce a major increase in micro hardness.

- The plasma-nozzle diameter does not affect essentially the weld-spot diameter.
- The energy efficiency of the plasma arc ranges between 40 and $50 \%$.

- The weld-spot diameters with plasma welding are smaller than with resistance welding. The optimum welding energy does not permit welding of weld spots with optional diameters.

- The bearing capacity of the plasma-spot welded joints is, taking into account the difference in the weld-spot diameters, proportionally comparable with the bearing capacity of the resistance-spot welded joints. The fracture strength is even higher than in resistance spot welding and the breaking forces as absolute values are smaller.

- The plasma spot welding process is suitable for welding ferritic stainless steels.

Several directions are open for investigation in the future. The in work confirms that the investigations conducted were justified.

\section{REFERENCES}

[1] K.F. KRYsiaK, Weld. J. 65 (1986) 37-41.

[2] Nichtrostende Stähle, H. Ordenbach (Ed.), Verlag Stahleisen, Düsseldorf, 1989.

[3] Conseils pour le Soudage des Aciers Inoxydables, Collection ATS/OTUA, 1990.

[4] T. EnJo, T. KURODA and R. IMANISHI, Trans. JWRI 16 (1987) $123-129$.

[5] J. HAMmOND and C.R. Gunstone, Weld. World 19 (1981) 172-184.

[6] Techniques de l'Ingénieur, Traité Métallurgie, M 320, 1-1-M 320, 1-5.

[7] V.A. ERmilov, A.S. ZubChenKo, Weld. Int. 6 (1992) 565 568.

[8] D.H. KaH and D.W. Dickson, Weld. J. 60 (1981) 135s142-s.

[9] J.C. LIPPOLD, A Review of the Welding Metallurgy and Weldability of Ferritic Stainless Steels, Institut de Soudure, IRSID, Paris, 1990.

[10] B. Aziz and R. Feen, Sheet Met. Ind. 60 (1983) 28-33.

[11] J. Tú̌EK, Rev. Metal. Madrid 37 (2001) 437-444.

[12] Aciers Inoxydables, P. Lacombe, B. Baroux and G. Beranger (Eds.), Les Editions de Physique, Les Ulis, 1990.

[13] E. Folkhard, Welding Metallurgy of Stainless Steels, Springer-Verlag, New York, 1987, pp. 20-138.

[14] MCKAY, Welding Stainless Steel.

[15] ANSI/AWS C5.1 Recommended Practices for Plasma-Arc Welding, American Welding Society, Miami, Florida, 1973.

[16] A. LĚ́NJAK, Vrailna tehn. (Ljubljana) 42 (1993) 111-117. 
[17] W.F. Smith, Structure and Properties of Engineering Alloy, McGraw Hill, New York, 1981.

[18] J. TǓ́EK, IEEE Trans. Plasma Sci. 28 (2000) 1688-1693.

[19] J. Tú̌K, Varilna teh. (Ljubljana) 43 (1994) 67-72.

[20] R.C. AsHauer and S. GOODMAN, Weld. J. 46 (1967) 405 415.

[21] S.P. FILIPISKI, Weld. J. 43 (1964) 937-943.

[22] B. LE Bourgeols, Soudage a l'arc, Tome 1, Tome 3, Publications de la Soudure Autogene, Paris, 1989.

[23] Welding Handbook, Vol. 2, R. L. O'Brien (ed.), 8th ed., American Welding Society, Miami, Fl., 1991, pp. 329. 350.

[24] G. DEN OUDEN, Doc. 212-184-70, International Institute of Welding (IIW), Paris, 1970.

[25] The Physics of Welding, J. F. Lancaster (Ed.), Pergamon Press, Oxford, 1984, pp. 109-203.
[26] V. KRALJ, Schweißtechnik (Berlin) 23 (1973) 249-251.

[27] L. BAUM and H. FISCHER, Der Schutzgasschweißer, Teil 1: WIG-Schweißen/Plasmaschweißen, Deutscher Verlag für Schweißtechnik (DVS), Düsseldorf, 1981, pp. 83-93.

[28] D. BöHmE, Proc. Welding Production Procedures Beam Technology -Aarc Welding Technology, Aachen, Germany, 1989, DVS-Verlag, Düsseldorf, 1989, pp. 78-91.

[29] M. Suban, Master Thesis, Faculty of Mechanical Engineering, University of Ljubljana, 1998.

[30] J. TUŠEK and M. SUBAN, Int. J. Hydrogen Energy 25 (2000) 369-376.

[31] J. Tưšk, Varilna tehn. (Ljubljana) 43 (1993) 8-12.

[32] I. POLAJNAR and F. KOSEL, Varilna tehn. (Ljubljana) 46 (1997) 127-132. 